\title{
SAĞLIK OMBUDSMANI
}

\author{
Health Ombudsman
}

Prof. Dr. Zakir AVŞAR* - Yrd. Doç. Dr. Kadriye AVCI*

Geliş Tarihi: 25.09.2016 Yayına Kabul Tarihi: 15.05.2017

\section{Öz}

Sağlık ombudsmanlığı, son 20-30 yılda ortaya çıkmış bir kavramdır. Bazı Avrupa ülkelerinde ve Amerika Birleşik Devletleri'nde, hasta haklarını korumak amacıyla giderek yaygınlaşmaktadır. Hastaların şikâyetlerine cevap vermek için kurulmuş olup, amaç kamuya sağlık hizmetleri sunumunu daha nitelikli ve sağlık çalışanlarını daha sorumlu hale getirmektir. Sağlık Ombudsmanı tarafından yapılan tavsiyeler doğrultusunda sağlık hizmetlerinin kalitesinen sürekli artırılması ve sağlık çalışanlarının kamuya karşı daha bilinçli ve sorumlu hale gelmesi mümkün olur. Birçok ülkedeki sağlık ombudsmanı uygulamaları, yetkileri ve konumu bakımından farklıdır. Çoğu sağlık ombudsmanı sadece hastalar ve sağlık kurumları arasında arabuluculuk yapsa da, bazılarının soruşturma yapma gibi güçleri de vardır. Sağlık ombudsmanlarının sadece bir bölümü merkezi bir yapıya sahipken, bazıları yerel ve bazıları da kurumsal düzeydedir. Bu makale, sağlık ombudsmanın tanımı, rolü, özellikleri ve bazı ülke uygulamalarının, literatür bilgileri eşliğinde ele alınması amacıyla gerçekleştirilmiştir.

Anahtar Kelimeler: Sağlık Ombudsmanı, Hasta Hakları, Sikâyet Yönetimi.

\begin{abstract}
Health ombudsman is a concept that has emerged in the last 20-30 years. In some European countries and the United States of America, it is becoming increasingly common to protect patients' rights. Established to respond to complaints from patients, the intention is to make health services and professionals more accountable to the public. It also increases the quality of health services in accordance with the advice given, and health workers make it more accountable to the public. Health ombudsman practice in many countries is different in terms of locations and powers. Most health ombudsman only act mediation between patients and health care institutions, some of them also has the power to make such an investigation. While only a part of the health ombudsman has a central structure, some are local and some are also institutional level. This article was carried out to evaluate the literature on health ombudsman definition, the role, features and practices of some countries.
\end{abstract}

Keywords: Health Ombudsman, Patient Rights, Complaints Management.

\footnotetext{
"Gazi Üniversitesi İletişim Fakültesi,

"*Afyon Kocatepe Üniversitesi Tip Fakültesi, orcid.org/0000-0001-8894-4142
} 


\section{GİRiş}

Bir olaya tepki vermek istendiğinde ya da bir haksızlığı maruz kalındığını düşünüldügünde şikâyet etme ihtiyacı, insanın doğasında vardır. Etkili bir şikâyet mekanizmasının varlığı, bir ülkenin vatandaşlarının duygularına ve tepkilerine cevap veren kurumlar bağlamında, günümüzde her alanda esastır. Sağlık gibi hassas bir konuda da, insanlar aldıkları hizmet sırasında bir ihlal ya da haksızlığa uğradıklarını hissettiklerinde şikâyet etme ihtiyacı duyarlar. Çoğu durumda, şikâyet sistemleri hasta hakları kapsamında, sağlık kurumlarının kendi içinde yer alan bir süreçtir. Kendi içlerindeki sorunlar genellikle hem şikâyetçiyi hem de sağlık çalışanını hoşnut edecek şekilde çözülmeye çalışılır. Fakat bu sistem genellikle şikâyetçiye karşı pek şeffaf değildir, soruşturma yapılmayabilir ve kurum içi işleyişi ait problemlerin düzeltilmesine karar verilse de genelde bu tür sorunların çözülmesine yönelik girişimler pek başlatılmaz.

Sağlık kurumlarının şikâyetleri kendi içinde çözümündeki bu sorunlar nedeniyle pek çok ülkede bağımsız ve tarafsız bir sistem arayışına girilmiştir. Genellikle sağlıkla ilgili temel politika değişikliklerine ya da hasta hakları ile ilgili yeni geliştirilen politikaların içeriğine adapte edilerek uygulanmaya başlatılan sağlık ombudsmanlığı, bu arayışa cevap vermek üzere hizmet vermeye başlamıştır. Başlangıçta hasta haklarını korumak amacıyla giderek yaygınlaşan bu sistem, aynı zamanda sağlık hizmetlerinde uygun olmayan işleyişlerin değiştirilmesi yönünde verilen tavsiyeler doğrultusunda sağlık hizmetlerinin kalitesini de arttırmaktadır. Bunun yanında sağlık hizmetlerini ve sağlık çalışanlarını kamuya karşı daha sorumlu kılmaktadır.

Günümüzde birçok ülkede var olan sağlık ombudsmanlığı hem yetkileri hem de konumu bakımından farklılıklar gösterir. Çoğu sağlık ombudsmanı sadece hastalar ve sağlık kurumları arasında arabuluculuk yapsa da, soruşturma yapma gibi güçleri olan da vardır. Sağlık ombudsmanlarının bir kısmı sadece merkezi bir yapıya sahipken, bazıları yerel ve bazıları da kurumsal düzeydedir. Bu uygulama farklılıkları çeşitli sorunları da beraberinde getirmektedir. Bazılarının yeterli güce sahip olmaması şikâyetlerin çözümünde yaptırımlar yönünden, bazı merkezi sağlık ombudsmanları da şikâyetlerin çözüm sürecinin uzaması nedeniyle, güven eksikliğine neden olabilmektedir. 
Rolleri ve fonksiyonları değişse de, sağlık ombudsmanlarının kamu bekçisi olarak sağlık alanındaki önemi tartışılmazdır. Bu makalede sağlık ombudsmanın tanımı, rolü, özellikleri ve bazı ülkelerdeki sağlık ombudsmanı uygulama örnekleri literatür bilgileri eşliğinde incelenmiştir.

\section{OMBUDSMAN VE SAĞLIK OMBUDSMANI}

Ombudsman kurumunun ilk öncülleri, İslam ve Türk devlet ve toplum hayatı içinde görülür. Kurumun Osmanlı'dan ilham ile İsveç'te kurulduğu bilinmektedir. Ombudsman kavramı İskandinav kökenli bir terimdir ve temsilci anlamına gelir. Ombudsman, vatandaşların bürokrasiden, kötü yönetimden kaynaklanan şikâyetlerini geniş yetkileri çerçevesinde, hızlı ve güvenli bir şekilde araştırıp çözüm önerileri sunan; yetkin, tarafsız, bağımsız, yasal, atanmış veya seçilmiş yetkilidir. Ombudsmanın rolü, hakların ihlali, gücün kötüye kullanımı, hata, ihmal, haksız karar ve kötü yönetime karşı kamuyu korumak ve hükümetlerin eylemlerini daha şeffaf ve kamuya karşı daha sorumlu yaparak kamu yönetimini iyileştirmektir. Parlamento ya da hükümet tarafından atanan kamu hizmeti ombudsmanları, genellikle kamu sektörünün bazen de özel sektörünün elemanlar ile başa çıkmak için geniş yetkiye sahiptir. Ombudsman halktan gelen şikâyetlere tavsiye ya da uzlaşma ile cevap verir, yetkileri çeşitlilik göstermesine rağmen, güçlü düzenleyici yöntemlerle yaptırım uygulayabilir ve dava açabilir (Avşar, 2012; Healy ve Walton, 2016).

Ombudsmanlık kurumu bu günkü anlayış içinde 1809 yılında İsveç'ten köken almasına rağmen, İsveç Parlamentosu ombudsmanın sadece bir İsveç kurumu olmadığını belirtmiş ve tüm insanlık için bir kuruma dönüştüğünü açıklamıştır. Ombudsmanlık kurumu, farklı ülkelerde ve farklı fonksiyonlarda adapte edilen ve çoğaltılan kurumlar olarak yaygınlaşmıştır. Uluslararası Ombudsman Enstitüsü, 2015 yılında, 85 ülkede 150'den fazla kamu sektörü üye kurumlarını listelemiştir. Günümüzde, uluslararası düzeyde, devlet düzeyinde ve yerel yönetimlerde görev yapan ombudsmanların yanı sıra ihtisas ombudsmanlarına (askeri, tüketici, çocuk, sinema, basın, sağlık ombudsmanları vb.), ticari ombudsmanlara (banka, sigortacılık, taşımacılık ombudsmanları vb.) ve bulundukları yerlere göre (aile, üniversite) ombudsmanlara rastlanmaktadır (Avşar, 2012; Healy ve Walton, 2016). 
Sağlık ombudsmanlığı son 20-30 yılda ortaya çıkmış bir kavramdır. Birçok Avrupa ülkesi ve Amerika Birleşik Devletleri (ABD)'de hasta haklarını korumak amacıyla giderek yaygınlaşmaktadır. Sağlık ombudsmanları, kendi çekirdek yetkileriyle vatandaşların mağduriyetlerine doğrudan cevap verildiği sağlık sektöründe benzersiz bir düzenleyici olarak dikkat çekerler. Sağlık ombudsmanı vatandaşlar ve devlet kurumları arasında güvenilir bir aracı olarak kamu bekçisi hizmeti verirler. Gelişmekte olan halk sağlığ1 ombudsmanları, bir sosyal kontrol aracıdır ve kamu yönetiminin fonksiyonlarının kontrolünde, vatandaşlar arasında adaletin yayılmasında ve bir başarısızlığın kınanmasinda önemli fonksiyonu vardır (Fallberg ve Mackenney, 2003; Mok vd., 2010; Silva vd., 2014).

Günümüzde yeniden yapılanan kamu sağlık sektörü, baskın ve otoriter bir düzenleyiciden ziyade hem devlet ve hem de devlet dışı aktörler tarafından değişik stratejilerin karışımıyla çok merkezli yönetim ile karakterize hale gelmektedir. Bu alanın düzenleyici mimarları, sadece merkezi bir komuta ya da kontrol merkezi tarafından ya da sağlık profesyonellerinin kendileri tarafından değil, 'az ya da çok birbirine bağlı yönetim ağları' oluşturan aktörlerin birçoğu tarafından üstlenilmiş şekilde, sağlık sektörü yönetimini yeniden düzenlemektedir. Bu çerçevede birçok ülkede sağlık uygulama yönetmeliği, kalite ve güvenlik için sağlık hizmeti sağlayıcılarını daha sorumlu yapmak üzere yeniden şekillenmektedir. Böylece farklı ülkelerde değişik düzenlemelerle sağlık hizmeti sağlayıcılarının hesap verebilirliği güçlendirilmiştir (Healy ve Walton, 2016).

Sağlı ombudsmanlığı, genellikle sağlık hizmeti uygulamasındaki bu temel politika değişikliklerine adapte olmuş modellerdir. Örneğin İngiltere' de sağlık ombudsmanı 1973'te Ulusal Sağlık Hizmetleri (National Health Service: NHS)'nin yeniden yapilandırmasında doğmuştur. Buna karşılık Finlandiya' da 1992' de çıkarılan hasta hakları yasası ile yürürlüğe girmiş ve bununla birlikte merkezi bir ombudsman yerine yüzlerce yerel kurumlar seviyesinde, genelde hemşire ve sosyal çalışmacılardan oluşan ombudsmanlar atanmıştır (Fallberg ve Mackenney, 2003). 


\section{SAĞLIK OMBUDSMANININ ÖZELLIKLLRİ}

Sağlık ombudsmanının en önemli özelliği belirli bir yetkisinin olmasıdır. Diğer önemli özellikleri ise tarafsızlık, dürüstlük, yeterliliğinin ve sistematik bir yaklaşımının olmasıdır.

\section{Yetkileri}

Ombudsmana saygı için yasal yollar gerekli değildir ama tavsiyelerini ve soruşturmalarını takip edecek yeterli yetkiye de sahip olmalıdır. Bazı ülkelerde bu yasal süreçler sadece ombudsmana duyulan saygıya dayanır. Buna rağmen çok az gücü varsa güvenilir olmayan ve kararları başkaları tarafından göz ardı edilebilen bir kurum haline dönüştürebilir (Fallberg ve Mackenney, 2003).

Sağlık ombudsmanların görev analizinde yetkileri bakımından üç temel model ortaya konmuştur: Standart veya klasik, hukuki süreçler ve insan hakları. Standart modelde bir ombudsmanın üç temel görevi vardır: Bir şikâyeti sorgulama, çözümüne yönelik tavsiyelerde bulunma ve bu aktiviteleri kamuoyuna raporlama. Bu tip ombudsman üçüncü bir taraf gibi davranır. Hukuki süreçler modelinde daha fazla güç sahibidir, soruşturma ve kovuşturmaları başlatabilir ve bazı mahkemelerin idari kararlarına itiraz edebilir. İnsan hakları modelinde, bir ombudsman anayasa mahkemelerindeki idari kararlara itiraz yetkisine sahiptir (hukuki süreçler modeline benzer), ancak insan haklarını korumaya odaklanmıştır ve insan hakları konusunda hükümete tavsiye yetkisine sahiptir. Böyle bir ombudsman, kamu raporları gibi mekanizmalar aracılığıyla politikacıları ve kamuoyunu etkilemeyi amaçlamaktadır (Healy ve Walton, 2016).

Sağlık ombudsmanlarının şikâyetleri ele alma süreci diğer ombudsmanlarınkine benzer. Vakaların çoğu düzenleyici piramidin yumuşak tabanı etrafında ele alınmıştır: Dinleme, tavsiye, şikâyetçileri hizmet sağlayıcılara yönlendirme ve hizmet sağlayıcıdan bir açıklama/özür ile olayları çözme. Piramidin tepesine çlkılınca daha yoğun ve daha pahalıya mal olan düzenlemeler mevcuttur: Resmi soruşturma, değişiklik tavsiyesi, yaptırım uygulama, isimleri ve yaptırımları yayınlama ve dava açma (Şekil 1). Çok az vaka soruşturma ve kovuşturmaya dönüşür. Bazı sağlık ombudsmanları bireylerin şikâyetlerini çözecek güçte 
olmamalarına rağmen, çoğu sistematik bir problemin soruşturması başlatmak için yeterli bağımsız güce sahiptir (Healy ve Walton, 2016).

\section{Şekil 1. Sağlık ombudsmanının düzenleyici mekanizmaları}

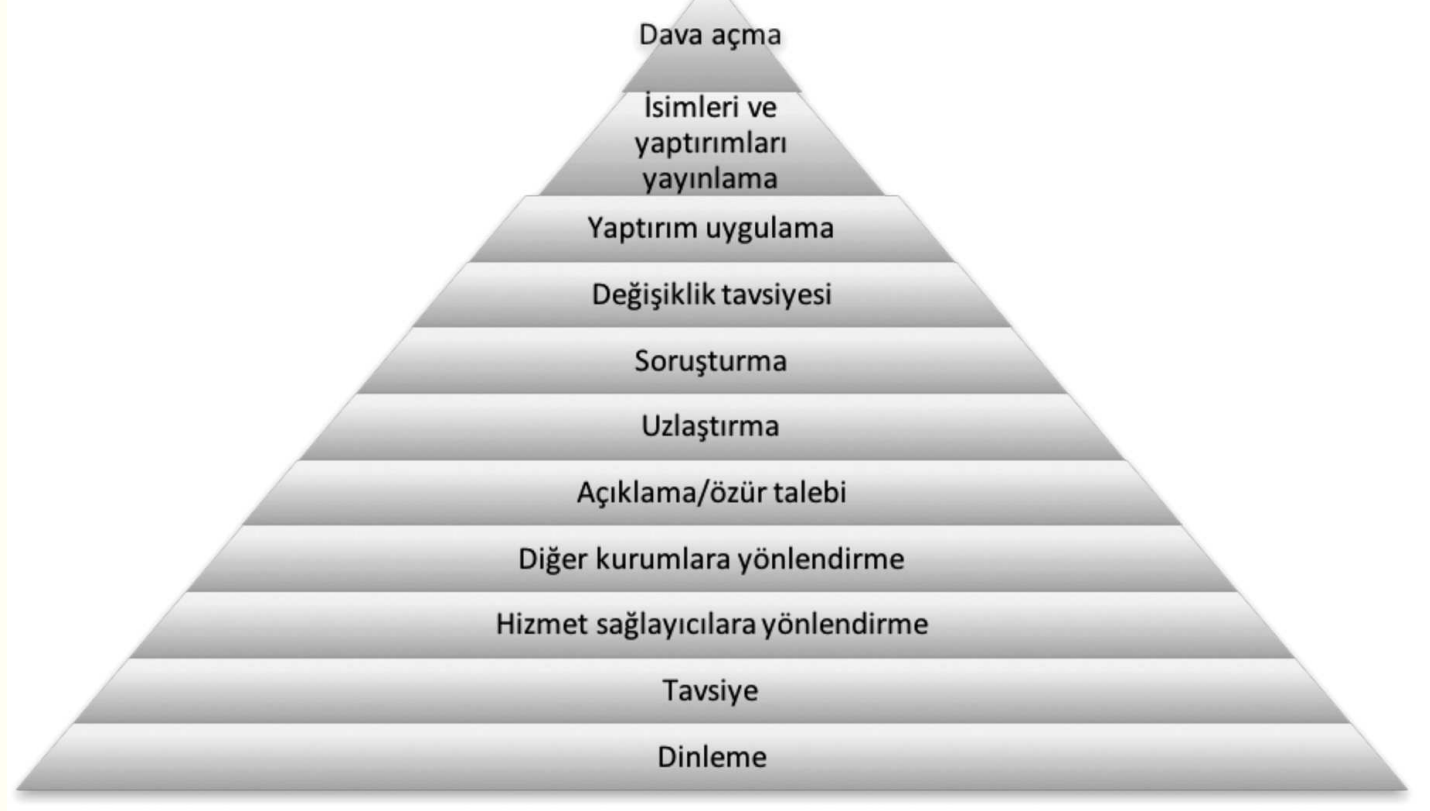

Sağllk ombudsmanının insanlar tarafindan algılanan temel felsefesi, sağlık hizmeti sağlayıcılarından özür ya da açıllama istemek için başvurulan bir yer şeklindedir. Bu uygulamanın olduğu ülkelerde yapılan çalışmalarda vatandaşlar, sağlık ombudsmanına daha fazla cezalandırıcı yetki verilmesi gerektiğini ve beklentilerinin karşılanmadığını belirtmişlerdir. Avustralya'da 2013-2014 yılında sağlık ombudsmanına başvuran kişilerden Queensland'da \% 46’sı, Victoria da \% 65’i şikâyetlerinin sonucundan memnun olmadıklarını ifade etmişlerdir (Healy ve Walton, 2016).

\section{Tarafsızlık}

Sağlık ombudsmanının işlevleri bir dereceye kadar etkin bir şikâyet sistemi ile aynıdır. Şikâyet eden ve şikâyet hakkında karar alan sistem arasında güven ilişkisi çok önemlidir. Böyle bir güven ilişkisinin olabilmesi için sağlık ombudsmanının tam bağımsız olması gerekir. Bağımsızlık, idari ve yasal olarak güçlendirilmiş olmalıdır. Tarafsızlık da bir şikâyet ve soruşturma sonundaki önerlerle temsil edilmelidir. Bu 
öneriler ataerkil yaklaşımlar veya geleneksel uygulamaların etkisinde olmamalı, ilgili kurumların kalitesinin iyileştirilmesi ile birlikte bireyin haklarına odaklanmalıdır. Şikâyetlere gerçek bir şekilde odaklanan sağlık ombudsmanlarının aynı zamanda bireysel olarak da kendi mesleki itibar ve dürüstlük açısından önemli bir kişisel kazançları olacaktır (Fallberg ve Mackenney, 2003).

\section{Bağımsızlık}

Pek çok paydaşı ile çatışma içinde olan sağlık ombudsmanı hem sistem içinde hem de bireylere karşı bağımsız olmalıdır. Herhangi bir bakış açısına sempati hissedildiğinde sağlık ombudsmanının eleştirilme riski vardır. Kesinlikle bir şikâyet hakemi gibi hareket etmeli, bağımsız ve tarafsız olmalıdır. Tarafsızlık, ombudsmanı şikâyetçinin gerçek danışmanı ve savunucusu olarak gören herkes için bir ön koşul olmalıdır (Fallberg ve Mackenney, 2003).

\section{Yeterlilik}

Sağlık ombudsmanının yaptığı iş konusunda yeterli eğitime sahip olması gerekir. Genellikle, sağlık profesyonelleri dilini anlayan klinik deneyime sahip birisi olması tercih edilir. Ayrıca yasal konularla ilgili de eğitim almış olmalıdır (Fallberg ve Mackenney, 2003).

\section{Sistemik bir yaklaşım}

Şikâyetler herhangi bir hizmet sistemindeki değişiklikleri oluşturmak için yararlı bir araçtır. Ancak, uzun süredir iyi bir şekilde olduğu düşünülen bir davranışı değiştirmek için iyi kanıt gerekir. Bu tür kanıtlar toplamak için, tüm şikâyetlerin tespit edilip belgelenmesi, kategorize ve analiz edilmesi, sistematik bir şekilde ele alınmasını son derece önemlidir. Eğer bu şekilde sistematik uygun veri toplanırsa, söz konusu birimin kalitesini iyileştirmek için de bir şans olacaktır (Fallberg ve Mackenney, 2003).

\section{BAZI ÜLKELERDE SAĞLIK OMBUDSMANLIĞI UYGULAMALARI}

Bazı ülkelerdeki sağlık ombudsmanlığı uygulamaları aşağıda verilmiştir. Bu ülkelerden sistemin en köklü olduğu İngiltere daha ayrıntılı 
incelenmiştir. Yine İngiliz kökenli sağlık ve ombudsmanlık sistemleri olan Yeni Zelanda ve Avustralya'ya da yer verilmiştir. Bunların dışında Avrupa'da sağlık ombudsmanlığı sistemi olan Avusturya, Finlandiya, Yunanistan, Macaristan, İsrail ve Norveç'deki uygulamalar da ele alınmıştır. ABD'de ise genel sağlık ombudsmanı olmamasına rağmen, bakımevlerinde kalan hastalar için uygulanan ombudsmanlık sistemi burada yer almaktadır.

\section{İngiltere}

İngiltere'de bağımsız, ulusal temelli bir araştırmacı olarak geleneksel ombudsman modeli benimsenmiştir. Başlangıçta genel parlamento ombudsmanı şeklindeyken daha sonra sağlık ombudsmanı olarak özelleşmiştir. İngiltere'de sağlık ombudsmanı ve parlamento ombudsmanı ikiz ombudsmanlardır. Sağlı hizmetleri ombudsmanı NHS yasasının yeniden düzenlendiği 1973'de, NHS'nin hesap verebilme eksikliğini gidermek amacıyla, parlamento ombudsmanının görev alanı dişında kurulmuştur. Hastalara bu savunuculuk sistemini desteklemek ve şikâyet prosedürleri hakkında rehberlik için bazı uygulamalar geliştirilmiştir: Her sağlık kurum içinde çalışan bir hasta danışma ve irtibat hizmeti ve resmi bir şikâyette bulunmak isteyen hastalar için yasal olarak bağımsız şikâyet yapma hizmeti (Fallberg ve Mackenney, 2003; Healy ve Walton, 2016).

Bağımsızlığı yasalarla korunan sağlık sistemi ombudsmanı çoğu gücünü 1993 Sağlık Hizmetleri Komiserleri Yasasından (Health Service Commissioners Act) alır. Bu yasa NHS ve diğer kamu kurumlarında uygulanır, özel sektörde uygulanmaz. Sağlık hizmeti ombudsmanı standart modele uyar, ama 'hukuki süreçler' unsurları ile hizmet sağlayıcılardan cevap alma ve yaptırım uygulama gücünü kullanır. Bu çalışma alanı içinde ombudsmanın tanık çağırmak için ve kayıtları erişmek gibi güçleri de vardır. Ancak tavsiyelerinin yerine getirildiğini denetleme yetkisine sahip değildir (Fallberg ve Mackenney, 2003; Healy ve Walton, 2016).

İngiltere'de merkezi bir sistem olduğu için en büyük sorun başvuruların sonuçlandırılmasında gecikme olmasıdır. Parlamento ve sağlık ombudsmanı Julie Mellor, birçok şikâyetin yerel çözülebileceğini, şikâyetlerin sonuçlandırılmasında ve hizmetlerin iyileştirilmesinde 
bazı gecikmeler olduğunu, bir yılda yaklaşık 4000 şikâyet alındığını ve bunların \% 37'sinin onaylandığını belirtmiştir.

İngiltere Hastalar Birliğini'nin 2015 yılı raporuna göre, sağllk ombudsmanına başvuranların $2 / 3$ si araştırmanın düzeyi ya da son rapordaki bazı içeriklerle ilgili (yanlış, zayıf gerekçeli ya da tutarsız olduğu) hastalar birliğine başvurmuştur. Bu raporda, başvuruların en sık nedeninin iletişimin uzun sürmesi ve buna bağlı duygusal tükenme olduğu belirtilmiştir. Bunların yanında diğer önemli şikâyet sebepleri ombudsmanların NHS'ye meydan okumada isteksiz ve yetersiz olması, şikâyet kapsamının daraltılması ve önerilerin etkisiz olmasıdır (Tingle, 2015).

İngiltere'da sağlık ombudsman sistemine başvuruların ve değerlendirilmesinin daha iyi anlaşılması bakımından aşağıda iki örnek vaka verilmiştir:

12 yıldır yüz ağrısı olan bir vaka şiddetli ağrı nedeniyle 1997'de başvurduğu sağlık kurumundan defalarca Manyetik Rezonans Görüntüleme (MRG) istemesine rağmen, 2012 yılı için MRG taraması için tarih verilmiştir. Taramanın arakasından yüz ağrısının tanısı konulmuş ve cerrahi girişimle tedavi edilmiştir. İncelemenin ardından hastaya 2010 yılında MRG tarama yapılabileceği tespit edilmiştir. Ombudsmanın kararı sonrasında, gecikme için özür dilenmiş ve ağrı ve strese yol açması nedeniyle hastaya $750 £$ ödenmiştir.

Diğer bir vakada kalçasında ağrılı bir kitlesi olan bir adam hastaneye başvurduktan sonra, tıbbi ve cerrahi tedavi yapılmaksızın evine gönderilmiş. Üç hafta sonra şiddetli ağrıyla hastaneye tekrar başvurmuş. Doktorlar enfeksiyonun yayıldığını tespit etmiş ve hasta sepsisten hayatını kaybetmiş. Ombudmanın hastanın ilk başvurusunda gerekli tedavinin yapılmadığını tespit etmiş. Şikâyet eden hastanın kızından özür dilenmiş ve $200 £$ ödenmiştir (Wise, 2015).

\section{Yeni Zelanda}

Yeni Zelanda'da soruşturma için meclis komiseri 1962 yılında kurulmuştur. Sağlık ombudsmanı bundan üç dekad sonra 1994 yılında Sağlık ve Engelliler Komiserliği Yasası altında, Yargıç Cartwright'in bağımsız bir komiser ve hasta hakları kodu çağrısından sonra atanmıştır. Cartwright soruşturması, Auckland Kadın Hastanesinde erken 
servikal kanser belirtileri araştırılan fakat tedavi edilmeyen kadınlar1 araştırmak amacıyla yürütülmüştür. Yeni Zelanda Komisyonu üç ombudsman modelin unsurlarını içerir: Standart model, bazı 'hukuki süreçler'in güçleri ve tüketici haklarının savunusuyla insan hakları modeli. Sağllk ve Engelliler Komiseri, yasal olarak uygulanabilir haklarını belirleyen ve kamu ve özel sektör hizmet sağlayıcılarının gelen tüm görevleri kapsayan, 1996 Sağlık ve Engelli Hizmetleri Tüketici Haklarına Kural ihlallerini inceler. Dahası, komiser mahkemeden önce soruşturma başlatabilir (Healy ve Walton, 2016).

\section{Avustralya}

Federal ombudsman Avustralya Hükümeti bölümleri hakkında şikâyetlere cevap vermek için 1976 Ombudsman Yasası altında kurulmuştur. Altı eyalet ve iki bölgenin, kamu kurumları, yasal otoriteler, yerel yönetimler ve kamu üniversiteleri ile ilgili şikâyetlere cevap veren 1970'lerden beri yasal ombudsmanlarının kurulmuştur. 1980'lerden itibaren sağlık şikâyetleri komiserleri tüm eyalet ve bölgelerde atanmıştır. Sağlık çalışanları hakkındaki şikâyetlere tıbbi kurulların yanıtlarına memnuniyetsizlik, kamu ve özel hastanelerde şikâyetler ilgili bağımsız birimlerin eksikliği ve tıbbi skandallardan sonra daha fazla sorumluluk talebi yönündeki ivme sağlı ombudsmanlığına hız kazandırmıştır. Dahası, Avustralya Sağlık Anlaşması ve 1992'de değiştirilen Medicare anlaşması eyalet ve bölgelerde, bağımsız şikâyet organları kurumunu gerektirmekteydi.

Sağlık şikâyetleri komiserinin etkileri, yapısı ve işlevleri, bağlı olduklara yasalar ve mevzuata göre değişir. Fakat tüm yasal kuruluşlar özel ve kamu sağlık çalışanları ve sağlık hizmetleri hakkındaki tüketici şikâyetlerine cevap vermek amacıyla kurulur ve yinelenebilir sabit bir dönem için atanan komiserler devlet bütçesi aracılığıla finanse edilir (Healy ve Walton, 2016).

\section{Avusturya}

Avusturya'da sağlık ombudsmanı sistemi 'Halkın Avukatı' çerçevesinde, hastalar için yasal savunma hizmetinin sağlanması etrafında döner. Birkaç nadir durumda takviye ihtiyacına rağmen genelde yerel ombudsmanlar bölgesel düzeyde benzersiz faaliyetler gösterirler. 
Yasal olarak bağımsızdırlar ve sağlık kurumları başka kaynaklardan onlara fon sağlayarak, açık bir şekilde bağımsızlıklarını ortaya koyarlar. Hasta savunucuları kendi seçtikleri uzmanlık alanında becerilerini ortaya koyarlar. Onlar, yargı dışı bu görevlerini her yerde yapabilirler. Çalıştığı kurumda yüksek derecede kabul görürler ve kamu kurumlarında istedikleri bilgiye ulaşabilirler (Fallberg ve Mackenney, 2003).

\section{Finlandiya}

Yerel yönetimler düzeyinde, yerel sağlık kurumları içinde hastalara danışman olarak bu hareket, 2,000 kişiden oluşan bir ağdan oluşur. Ulusal bir sisteme dayanır ve amacı hasta haklarını korumaktır. Tüm sağlık kurumları ombudsman çalıştırmak zorundadır.

İlginçtir ki, kamu denetçileri olarak görev yapan bireyler büyük ölçüde yarı zamanlı atanmışlardır. Onlar zamanlarının geri kalanında için sosyal çalışmacı veya hemşire olarak bu kurumların kamu çalışanlarıdır. Bağımsızlık ve çıkar çatışması sorunları, bu nedenle bu sistemde en üst seviyededir. Bunun yanında eğitim ve beceri eksikliği de önemli sorundur. Bu ombudsmanlar genelde bilgi sağlayıcı olarak görülür.

Güçleri genellikle sınırlıdır. Yetkileri belirsiz olmakla birlikte eleştirel bir tavsiye sunma yetkiler yoktur. Hasta Hakları mevzuatının uygulanmasında henüz tam olarak yasanın ruhu ve özgün niyeti yansıtmadığını ve ombudsmanın yetkilerinin azlığı haklı eleştirilere neden olmaktadır (Fallberg ve Mackenney, 2003).

\section{Yunanistan}

Ombudsman Yunanca'da tam anlamıyla bir 'Vatandaş Avukatı' olarak çevrilen bir ifade olmasına rağmen, arabulucuk ve araştırmacılık yapan klasik bir işlev görür. Ombudsmanlık, vatandaşların başvurdukları yetersiz geleneksel mekanizmalarına yanıt olmuştur. Açıkça ve yasal olarak iyi yapılandırılmıştır ve bağımsızdır. Geniş yelpazede bir ekiple çalışır, bu sayede tıbbi danışma için uzman görüşü alınması gerektiğinde bu ekip devreye girer. Ombudsmanın kayıtlara erişim ve tanık çağırma ile soruşturma yapabileceği geniş çaplı yasal yetkileri vardir. 
Ombudsmanın bu yetkilerini kullanma becerisi pek açık değildir. Çünkü ombudsmanın faaliyetleri hakkında pek rapor yoktur. Sağlık hizmetleri ombudsmanın faaliyet alanının küçük bir bölümüdür ve bireyler de henüz bu sisteme başvurmaya çok alışık değildir (Fallberg ve Mackenney, 2003).

\section{Macaristan}

Ombudsman fonksiyonlarının Macar modeli, İngiltere'deki gibi merkezi, yasal ve parlamentonun kamu bekçiliği konumundadır. Bir Parlamento Komiserinin araştırma yapabilmek için yaptırımları olan geniş geleneksel güçleri vardır. Macar Parlamento Komiseri azınlık hakları ve veri koruması gibi alanları da kapsayan bir dizi insan hakları konusunda yetkindir. Sağlık hizmetleri özel bir alan değildir, ancak insan hakları ve hasta hakları örtüştügü yerde, ombudsman tarafından ele alınır ve araştırılır. Bunlara yasal olarak atanır, yetkileri alanındaki hasta haklarını bağımsız araştırmak için istihdam, mülakat ve kayıtlara erişim hakları vardır. Hem ulusal ombudsmanı hem de yerel hasta hakları temsilcileri, Macar halkı tarafından kullanılan mekanizmalar$\operatorname{dir}$ (Fallberg ve Mackenney, 2003).

\section{İsrail}

İsrail yaklaşımı dünyada yasalarla kabul edilen en kapsamlı ombudsmanlık uygulamasıdır. Temel yasal yükümlülüklerini desteklemek için gayri resmi ve geleneksel mekanizmaların olduğu İngiltere'nin aksine, her düzeyde ombudsmanlar yasal olarak seçilirler.

Bir merkez Sağlık Sigortası Ombudsmanı, hasta haklarının korunması ve şikâyetlerin araştırılması sorumlu her sağlık kurumuna bir iç ombudsman ataması yaparak özel sağlık sigortalarına yasal yükümlülüğünü yerine getirir. Sistem her seviyede erişilebilme, soruşturma yetkisi ve bireylere desteği içerecek şekilde kapsamlıdır. Ancak ombudsmanı verilen herhangi bir işin kalitesini ölçebilecek beceri ölçütleri yoktur. Ayrica bölgesel yetki devirleri sistemin koordinasyonu ve tutarlığında sorunlara yol açmaktadır. Daha ötesi, sağlık fonu ile ombudsmanlar arasında olabilecek çıkar çatışmaları endişelere yol açabilmektedir (Fallberg ve Mackenney, 2003). 


\section{Norveç}

Norveç'de sağlık ombudsmanı başlangıçta ulusal bir kurum olarak uzun süre ayakta durmuşken, daha sonra ilçe düzeyinde hasta ombudsmanları atanmıştır. Bu kurumların rolleri ve sorumluluklarıyla ilgili çeşitli varyasyonlar vardır. Onlar açıkça bağımsızdır, ancak görevleri diğer ülkelerdeki birçok kurumun görevlerinin birleştirilmesinden oluşturulmuş gibidir. Norveç'de hasta ombudsmanı resmi soruşturma ve yargılama hakkı bulunan, hastaya tavsiye veren ya da alternatif şikâyet yolları gösteren resmi olmayan bir arabulucu olarak görülür.

$\mathrm{Bu}$ rollerin birleşmesi iyi durmaktadır ve ön planda tarafsızlık ve bağımsızlık vardır. Sağlık çalışanı ombudsmanı iç güvenlik ve kaliteyi arttırıcı bir faktör olarak görmektedir. Henüz ulusal düzeyde bir değerlendirme olmamasına rağmen yerel kurumlar hasta ombudsmanından memnuniyetlerini ifade etmişlerdir. Gerçekten de, hastane yönetiminin kalite iyileştirme çalışmalarına katkıda bulunmak için hasta ombudsmanı davet edebildiği anlaşılmaktadır. Bu onların rollerinin görünen yüzüdür. Bununla birlikte uzmanlık alanlarında, özellikle yasal konularda minumum düzeyde de olsa beceriye ve ülke düzeyinde tekdüze bir yapıya ihtiyaç vardır.

Hasta Kamu denetçileri sağlık hizmeti sağlayıcıları bile bilgi edinme, görüşme ve kayıtlara erişmek için çeşitli kanuni yetkileri vardır. Onların gerçek bir yaptırım uygulama güçleri yoktur. Yaptırım ve yasal güç o bölgenin sağlık yöneticisine aittir. Bu nedenler yaptırımlar nadiren uygulandığı için sağlı kurumları ombudsman bulundurmayı pozitif bir güç olarak görürler.

Ulusal Parlamento Komiserine çok az şikâyet gitmesine rağmen, hasta ombudsman sistemi son derece iyi kullanılır. Ayrıca onların asıl amaçları hasta haklarını savunmak olsa da yerel kaliteyi iyileştirme işlevleri de vardır (Fallberg ve Mackenney, 2003).

\section{Amerika Birleşik Devletleri (ABD)}

ABD'de genel bir sağlı sistemi ombudsmanı yoktur, uzun süreli bakım evlerinde yaşayanların haklarını korumaya yönelik Uzun Süreli Bakım Ombudsman programı geliştirilmiştir. Uzun Süreli Bakım Ombudsman programı, uzun süreli bakım sakinlerinin sağlık, güvenlik ve refahını savunan en büyük ve en köklü ulusal bir programdır. 
Başlangıçta Halk Sağlığı Servisi aracılığıyla gönüllü bir devlet programı olarak oluşturulan program, Yaşlı Amerikalılar Yasasında bir değişiklikle 1978 yılında ulusal düzeyde uygulanmaya başlanmıştır. "Uzun süreli bakım merkezlerinde kamunun varlığı" olarak nitelendirilen ombudsmanlar, uzun süreli bakımevi sakinlerini etkileyen bireysel ve sistemler düzeyinde sorunları tespit araştırmak, araştırmak ve şikâyetleri gidermekle görevlidir. Program genişledikçe evde bakım yapılan evler ve bazı kurullar da dahil edilmiştir. Ombudsman çeşitli ajans ve toplum himayesinde bulunan hem gönüllüler hem de ücretli çal1şanlardan oluşabilir. Çoğu eyalette ombudsmanlık gönüllülük esasına dayanır. Bu programlarda 1186 tam zamanlı personel ve 9065 gönüllü çalışmaktadır (Bloemen vd., 2013; Huber vd., 2001; Shelley vd., 2015).

Uzun süreli bakımevlerinde kalan yaşlı yetişkinler zayıf ve işlevsel bağımlıdır. Çoğu temel ihtiyaçları için başkalarına muhtaçtır ve sıklıkla en yaygın iki hastalık olan kalp-damar hastalığı ve mental bozukluklar vardır. Bu nedenle bu bakım merkezleri sakinlerinin ve ailelerinin psikolojik ihtiyaçlarını ele almak zorunda kalırken, uygun fiziksel bakım vermekte zorlanmaktadır. Buralarda yaşayanlar savunmasız nüfus olarak kabul edilir ve bu nedenle onların haklarının savunması gündeme gelmiştir.

Uzun Süreli Bakım Ombudsmanın aktiviteleri:

- Şikâyetlere cevap ve problemleri araştırmak

- Uzun süreli bakımevlerinde kalanlar ve personeller arasındaki anlaşmazlıkları çözmek, resmi veya gayri resmi arabuluculuk

- Sakinler ve ailelerine iyi bakım uygulamaları ve hasta hakları ile ilgili eğitim vermek

- Sakinlerin hakları ve iyi bakım uygulamaları hakkında personeli eğitmek

- Toplum katılımını teşvik etmek, toplumu eğitmek ve yasaları teşvik etmek (Baker vd.,2014)

ABD' de 15.700 bakımevinde toplam 1,669,100 yatak bulunmaktadır ve ortalama kalış süresi 835 gündür. Buralarda, ulusal düzeyde, 2006-2013 yıllarında 11.749 istismar ve ihmal şikâyeti olmuştur (Bloemen vd., 2013; Shelley vd., 2015). 


\section{TÜRKIYYE'DE HASTA HAKLARI VE SAĞLIK OMBUDSMANLIĞI}

Ülkemizde hasta hakları uygulamaları ve bu çerçevede hastaların şikâyet mekanizmaları Hasta Hakları Yönetmeliği ile şekillendirilmiştir. Hastaların şikâyetleri, sağlık kurum ve kuruluşları bünyesinde hasta iletişim birimleri, Sağlık Bakanlığı web sayfasındaki Hasta Başvuru Bildirim Sistemi (https://hastahaklari.saglik.gov.tr/) ve Sağlık Bakanlığ İletişim Merkezi (SABİM) üzerinden alınmaktadır. SABİM ALO 184 telefon hattı ve web sayfasından (sabim.saglik.gov.tr/) şikâyet almaktadır. Şikâyetler hangi yolla yapılırsa yapılsın, değerlendirme şikâyetin söz konusu olduğu birimin bağlı olduğu ildeki il sağlık müdürlüğü hasta hakları kurulu tarafından yapılmaktadır. İl sağlık müdürlüğü; üniversite hastaneleri, askeri hastaneler ve özel sağlık kurum ve kuruluşları, kamu hastaneleri, ağız diş sağlığı merkezleri, aile sağlığı merkezleri ve toplum sağlığı merkezlerinden gelen başvuruları değerlendirmek, karara bağlamak, öneri sunmak ve düzeltici işlemleri belirlemek üzere Hasta Hakları Kurulu oluşturmaktadır (Resmi Gazete 01/08/1998; Sağlık Bakanlığ1 Hasta Başvuru Bildirim Sistemi 2016; SABİM 2016). Hasta haklarına 2005 yılında toplam başvuru sayısı 35.457 iken, 2014 yılında 168.254'e ulaşmıştır (Hasta Hakları İstatistikleri 2005-2014).

Ülkemizde ombudsmanlık kurumu da sağlık alanındaki şikâyetleri de değerlendirilmektedir. T.C. Kamu Denetçiliği Kurumu 2015 ylllık raporuna göre, toplam 6055 şikâyetin 130 (\% 2,15)'u sağlık alanındadır. Şikâyet edilen idareler bazında dağılıma bakıldığında Sağlık Bakanlığı'na ait şikâyet sayısı 193 (\% 3,19)'dir. Sağlık alanındaki toplam 130 şikâyetin \% 22,31'i raporlar, \% 21,4'ü hasta hakları alanında olup, bunları ilaç ve eczacılık (\% 5,38), aile hekimliği hizmetleri $(\% 3,85)$, kamu ve özel tedavi kurumları (\% 3,85), muayene randevu sistemi $(\% 1,54)$, acil servis ve ambulans hizmetleri (\% 1,54), hastane, poliklinik ve hekim talepleri $(\% 1,54)$ ve özel tıp merkezleri $(\% 0,77)$ izlemektedir, diğer 49 şikâyet $(\% 37,69)$ sağlıkla ilgili diğer alanlardadır (T.C. Kamu Denetçiliği Kurumu 2015 Ylllık Raporu).

Görüldüğü gibi ülkemizde hastalar şikâyetlerini öncelikle başvurdukları kurumlardaki sağlık iletişimi birimi ya da SABİM üzerinden yapmaktadır. Ombudsmanlık kurumuna sağlık alanındaki başvurular 
çok azdır. Bunun nedeni öncelikle vatandaşların böyle bir kuruma da başvuru yapabileceklerini bilmemeleri olabilir. Ayrıca diğer merkezi ombudsman modellerinde olduğu gibi sağlık alanına özel bir ombudsmanlık sistemi yoktur. Kamu Denetçiliği Kurumu 2015 yıllık raporunda verilen bir örnekte aile hekimliği sistemindeki ücret adaletsizliği üzerine bir aile hekiminin şikâyeti üzerine, ombudsman tarafından aile hekimleri arasında hakkaniyete uygun, eşit, adil ve dengeli şekilde dağıtılmasını sağlayacak düzenlemelerin yapılmasını talep etmiştir. Bu tür başvuruların artması ve değerlendirilmesi, hasta haklarının korunmasının yanı sıra sağlık sistemindeki bazı aksaklıkların tekrar gözden geçirilmesine ve sağlıkta kalite artışına olanak sağlayacaktır.

\section{SONUÇ}

Günümüzde hasta hakları çerçevesinde sağlık kurumları ve sağlık çalışanlarıyla ilgili şikâyetler giderek artmaktadır. Hastaların şikâyetlerine cevap vermede ve endişelerini azaltmada sağlı ombudsmanları önemli rol oynamaktadır. Özellikle sağlık sisteminin işleyiş̧i ile ilgili sorunların bu şekilde tarafsız ve bağımsız bir kurum tarafından ele alınması, uygun çözümlerin bulunması ve bunların uygulamaya geçişinde daha etkili olmaktadır. Bununla birlikte gelecekteki rolleri şikâyetçilerin beklentilerinin karşılanabilmesi için yeterince güce sahip olmalarına bağlıdır. Hastaların beklentileriyle birlikte sağlık çalışanlarının da saygısını kazandığında sağlık ombudsmanlığı daha da gelişecektir. Gücün yanında tarafsızlık, bağımsızlık, konusunda uzmanlık ve sistemde yasalarla belirlenmiş ilkelerinin olması diğer var olması gereken özellikleridir. Ayrıca sağlık ombudsmanın aldığı kararların farklı paydaşları tarafından kabul görmesi de ombudsmana güvenin göstergesidir. Bu temel ilkelere bağlı kalarak, her ülkenin kendine uygun geliştireceği sağlık ombudsmanı uygulamaları hasta hakların güvencesi olacaktır. 


\section{KAYNAKÇA}

AVŞAR, Zakir. (2012). Ombudsman: İyi Yönetilen Türkiye İçin Kamu Hakemi, Hayat, İstanbul.

BAKER, N.R., Jablonski, R.A. ve Moss, J.A. (2014). A Nurse Developed Toolkit For Long-Term Care Ombudsmen, Geriatric Nursing, 35(2), 111-3.

BLOEMEN, E.M., Rosen, T., Clark, S., Nash, D. Ve Mielenz, T.J. (2015). Trends in Reporting of Abuse and Neglect to Long Term Care Ombudsmen: Data from the National Ombudsman Reporting System from 2006 to 2013, Geriatric Nursing, 36(4), 281-3.

FALLBERG, L. ve Mackenney, S. (2003). Patient Ombudsmen in Seven European Countries: An Effective Way to İmplement Patients' Rights?, European Journal of Health Law, 10, 343-357.

HASTA HAKLARI İSTATİSTİKLERİ 2005-2014. http://www.saglik.gov. tr/Hastahaklari/belge/1-39073/hasta-haklari.html, Erişim tarihi 22.09.2016.

HASTA HAKLARI YÖNETMELİ̆̄̇̇ (1998). Resmi Gazete 23420, 01.08.1998.

HEALY, J. ve Walton, M, (2016). Health Ombudsmen in Polycentric Regulatory Fields: England, New Zealand, and Australia, Australian Journal of Public Administration, Early View, Version of Record online: 6 MAR 2016.

HUBER, R., Borders, K., Netting, F.E. ve Nelson, H.W. (2001). Data From LongTerm Care Ombudsman Programs in Six States-The İmplications of Collecting Resident Demographics, The Gerontologist, 41,61-68.

MOK, E.A., Gostin, L.O., Das Gupta, M. ve Levin, M. (2010). Implementing Public Health Regulations in Developing Countries: Lessons from the OECD Countries, Journal of Law, Medicine \& Ethics, 38(3), 508-19.

SABİM. sabim.saglik.gov.tr/ , Erişim tarihi 22.09.2016.

SAĞLIK BAKANLIĞI HASTA BAŞVURU BİLDİRIM SİSTEMİ. https://hastahaklari.saglik.gov.tr/ , Erişim tarihi 22.09.2016. 
SHELLEY, G.K., Castro, C. ve Cron, S.G. (2015). Utilizing Online Tools to İncrease Volunteer Ombudsmen Presence in Long-Term Care, Geriatric Nursing, 36(1), 52-6.

SİLVA, R.C.C., Pedroso, M.C. ve Zucchi, P. (2014). Ombudsmen in Health Care: Case Study of A Municipal Health Ombudsman, Rev Saude Publica, 48(1),134- 41.

T.C. Kamu Denetçiliği Kurumu 2015 Ylllık Raporu. http://www.ombudsman. gov.tr/contents/files/2015\%20yillik\%20rapor\%20.pdf, Erişim tarihi 22.09.2016.

TINNGLE, J. (2015). Parliamentary and Health Service Ombudsman: Addressing The Failings, British Journal of Nursing, 24(10),542-3.

WISE, J.(2015). More Complaints Should Be Resolved Locally, Says Health Ombudsman, BMJ 2015;351:h5636. 